\title{
Decadal changes and delayed avian species losses due to deforestation in the northern Neotropics
}

How avifauna respond to the long-term loss and fragmentation of tropical forests is a critical issue in biodiversity management. We use data from over 30 years to gain insights into such changes in the northernmost Neotropical rainforest in the Sierra de Los Tuxtlas of southern Veracruz, Mexico. This region has been extensively deforested over the past half-century. The Estación de Biología Tropical Los Tuxtlas, of the Universidad Nacional Autónoma de México (UNAM), protects a 640 ha tract of lowland forest. It became relatively isolated from other forested tracts between 1975 and 1985, but it retains a corridor of forest to more extensive forests at higher elevations on Volcán San Martín. Most deforestation in this area occurred during the 1970 s and early 1980s. Forest birds were sampled on the station and surrounding areas using mist nets during eight non-breeding seasons from 1973 to 2004 (though in some seasons netting extended into the local breeding season for some species).

Our data suggested extirpations or declines in 12 species of birds subject to capture in mist nets. Six of the eight species no longer present were captured in 1992-95, but not in 20032004. Presence/absence data from netting and observational data suggested that another four low-density species also disappeared since sampling began. This indicates a substantial time lag between the loss of habitat and the apparent extirpation of these species. Delayed species loss and the heterogeneous nature of the species affected will be important factors in tropical forest management and conservation. 
2 David W. Shaw ${ }^{1,2}$, Patricia Escalante ${ }^{3}$, John H. Rappole ${ }^{4}$, Mario A. Ramos ${ }^{5}$,

3 Richard J. Oehlenschlager ${ }^{6}$, Dwain W. Warner ${ }^{5}$, and Kevin Winker ${ }^{1}$

$5 \quad{ }^{1}$ University of Alaska Museum, 907 Yukon Drive, Fairbanks, Alaska 99775 USA.

6

$7 \quad{ }^{2}$ Current Address: 1540 Jones Road, Fairbanks Alaska 99709 USA.

$9 \quad{ }^{3}$ Colección Nacional de Aves, Instituto de Biología, Universidad Nacional Autónoma de

10 México, Circuito Exterior s/n, Ciudad Universitaria, Copilco, Coyoacan, A. P. 70-233

11 Mexico, Distrito Federal. C. P. 14510 MEXICO.

12

13 4'Smithsonian's National Zoological Park, Conservation and Research Center, 1500

14 Remount Road, Front Royal, VA 22630 USA.

15

${ }^{5}$ Deceased.

${ }^{6}$ Science Museum of Minnesota, 120 W. Kellogg Blvd. St. Paul, MN 55102 USA.

Corresponding Author:

Kevin Winker

University of Alaska Museum

907 Yukon Drive

Fairbanks, AK 99775

kevin.winker@alaska.edu

907-474-7027 


\section{INTRODUCTION}

Deforestation is one of the main threats to biodiversity conservation. Forest loss and fragmentation have caused declines or local extinctions among animal species at many locations (Turner, 1996; Fahrig, 2003; Dirzo \& Raven, 2003). Local population declines and extiprations may be the most important leading indicators of biodiversity loss (Ceballos \& Ehrlich, 2002; O’Grady et al., 2004). Bird losses have been documented in many forest systems (e.g., Willis, 1974, 1979; Leck, 1979; Karr, 1982; Bierregaard \& Lovejoy, 1989; Kattan, Halvarez-Lopez, \& Giraldo, 1994; Robinson, 1999; Sodhi, Liow, \& Bazzaz, 2004; Ferraz et al., 2007; Patten, Gómez de Silva, \& Smith-Patten, 2010;

Laurance et al., 2011). Perhaps nowhere has this phenomenon been more noticeable than among tropical forests, where species losses have been documented in numerous taxonomic groups (e.g., Zimmerman \& Bierregaard, 1986; Powell \& Powell, 1987; Malcolm, 1988; Pahl, Winter, \& Heinsohn 1988; Becker, Moure, \& Peralta, 1991; Daily \& Ehrlich, 1995; Brook, Sodhi, \& Ng, 2003, Dirzo \& Raven, 2003, Stuart et al. 2004; Robinson \& Sherry, 2012). Species losses can occur at the landscape or patch levels and depend on the intensity of the change in forest cover, the distance to and size of other forest fragments, shape and size of the fragment, and other factors (Robbins, 1980; Lovejoy et al., 1984, 1986, Rolstad, 1991; Andrén, 1994; Faaborg et al., 1995; Lees \& Peres, 2006; Barlow et al., 2006; Patten \& Smith-Patten, 2011; Robinson \& Sherry 2012). Tropical forest species, which often occur in small, low-density populations, may be particularly vulnerable to extirpation (Terborgh \& Winter 1980; Pimm, Jones, \& Diamond, 1988; Stotz et al., 1996). Relatively few studies have assessed changes through decades, however (Ewers \& Didham, 2006). And although deforestation and fragmentation can occur over a short period, some time may pass before species begin to disappear from an affected area 
53 (Leigh, 1975, 1981; Karr, 1982, Tilman et al., 1994; Brooks, Pimm, \& Oyugi, 1999). Thus,

54 to fully document the impact of deforestation on a forest community, a site must be

55 studied for a substantial period of time after habitat alteration has occurred. Detailing

56 the process of local population decline and extirpation over time provides invaluable

57 information about species' abilities to cope with habitat fragmentation. It also informs us

58 about how community composition itself may be resistant to change, its degree of resilience following change, and how or if it stabilizes following this disturbance.

Studies of species losses in birds have used a variety of methods, including comparing species richness in different-sized fragments (Willis, 1979; Nemark, 1991; Blake, 1991), comparison of species composition at a site pre- and post-fragmentation (Willis, 1974; Leck, 1979; Bierregaard \& Lovejoy, 1989; Kattan, 1994; Patten \& SmithPatten, 2011), and experimental fragmentation (Lovejoy et al., 1986; Bierregaard \& Lovejoy, 1988, 1989; Ferraz et al., 2003, 2007; Laurance et al., 2011), and have often included scattered survey data prior to fragmentation (Willis, 1974; Leck, 1979; Kattan, Halvarez-Lopez, \& Giraldo, 1994; Robinson, 1999; Patten, Gómez de Silva, \& SmithPatten, 2010; Patten \& Smith-Patten, 2011). Many of these studies have relied on qualitative visual and audio survey techniques, with multiple observers, though such techniques can allow cryptic and low-density species to be overlooked (Whitman, Hagan, \& Brokaw, 1997). Additionally, observer skills and intensity of sampling may vary among surveys.

Mist netting offers the most consistent and quantitative method available to sample birds among years (Rappole, Winker, \& Powell, 1998). However, mist nets have

75 documented weaknesses; the most relevant is the limited stratum and size of birds they

76 can effectively sample (Remsen \& Good, 1996; Whitman, Hagan, \& Brokaw, 1997;

77 Rappole, Winker, \& Powell, 1998). This is particularly noticeable in structurally diverse 
78 habitats such as tropical rainforests, where probability of detection using mist nets is

unknown for most species. Mist net studies in the Neotropics are therefore biased toward understory, small- to mid-sized passerines. While mist nets, unlike other methods, are less prone to observer bias and variability, we augmented our analyses of netting data that suggested species losses with presence-absence observational data (daily checklists in later years); this becomes particularly important for low-density species and for those not readily captured.

The Sierra de Los Tuxtlas of southern Veracruz, Mexico provides a textbook case of deforestation. This small range of volcanic mountains is home to the northernmost Neotropical rainforest (Pennington \& Sarukhan, 1968; Dirzo \& Miranda, 1991). The region has lost more than $90 \%$ of its forests in the past century, with the majority of that loss occurring in the lowlands over the past fifty years (Dirzo \& Garcia, 1992; Rappole, Powell, and Sader, 1994; Winker, 1997). Our study compares eight seasons of mist net sampling from Los Tuxtlas over the course of more than thirty years. This allows us to at least partly answer the question of how species composition and relative abundance changed in and around a conserved core of local rainforest habitat on a decadal scale.

\section{METHODS}

The Sierra de Los Tuxtlas is located in southern Veracruz, Mexico, $90 \mathrm{~km}$ southeast of Veracruz city. This range of mountains lies in the northwestern portion of the Isthmus of Tehuantepec and is isolated from the Sierra Madre Oriental by extensive lowlands. Los Tuxtlas encompass approximately $4,200 \mathrm{~km}^{2}$, and the range is dominated by Volcán San Martín and Volcán Santa Marta, each reaching more than 1,500 m elevation. The Gulf of Mexico lies a short distance from the mountains to the north and east. The northernmost Neotropical evergreen rainforest formerly dominated the habitat in the region (Andrle, 1966; Pennington \& Sarukhan, 1968; Dirzo \& Miranda, 1991), but 
103 due to deforestation it is now a mosaic with a high percentage of pasture, cropland,

104 fencerows, and isolated trees (pers. obs.; Dirzo \& Garcia 1992; Estrada, Coates-Estrada,

$105 \&$ Merritt 1997). Andrle (1966) estimated that $50 \%$ of the region was forested in 1962. By

1061975 Rappole \& Warner (1980) estimated that a third of the forests still stood. Just 15\%

107 of forest remained in 1986 (Winker, Rappole, \& Ramos, 1990; Dirzo \& Garcia, 1992), and

108 in 1994 only $7-10 \%$ of the region was forested (Winker, 1997). Remaining forest occurs

109 primarily in the highlands, and below $500 \mathrm{~m}$ forest is scarce (Rappole, Powell, \& Sader,

110 1994; Mendoza, Fay, \& Dirzo, 2005; Figs. 1, 2, S1).

111 The climate in Los Tuxtlas is warm and wet, with a mean annual temperature of

$11225 \mathrm{C}$, and annual precipitation is $4,500-4,900 \mathrm{~mm}$, with a short dry season from March-

113 May (Soto \& Gama 1997). Canopy heights in primary forest range from 30-35 m (Ibarra-

114 Manriquez et al., 1997). Second growth areas generally have variable canopy heights

115 from 3-20 m (pers. obs.).

116 In 1967 the Universidad Nacional Autónoma de México established the Estación

117 de Biología Los Tuxtlas, protecting a 640-ha tract of lowland rainforest (González-

118 Soriano, Dirzo, \& Vogt, 1997). Over the following decades this site became largely

119 isolated from other tracts of forest, although a corridor of forest remains, connecting to

120 the more extensive upland forests on Volcán San Martín (Dirzo \& Garcia, 1992; Fig. 2).

121 The first intensive sampling of birds in the region began in 1973, and data from that

122 effort are included here (see Winker, 1997).

123 During the non-breeding seasons of 1973-74 and 1974-75 Oehlenschlager, Ramos,

124 Rappole, and Warner conducted the first intensive mist-netting efforts in the area. Sites

125 extended through what was then contiguous rainforest from the biological station

126 eastward to the coast (Fig. 3). In 1986, Rappole, Ramos, and Winker operated mist nets

127 at the biological station, and Winker and Escalante continued work there from 1992 to 
128 1994. In 2003-04 as part of a study of migrant birds, Shaw operated mist nets at the

129 same location as Winker and Escalante's work in the 1990s. This study was approved by

130 the University of Alaska Fairbanks IACUC (approval numbers: \#00-33 \& \#04-03).

131 Fieldwork occurred primarily during the non-breeding season. Effort was made to

132 equally sample the available forest types throughout the study period, although, in order

133 to do this, habitat changes precluded using the same sites across all years (see Winker

134 1995; Fig. 3). Field effort as gauged by net hours also varied among years (Table 1).

135 Our earliest sampling occurred over a wider area than later seasons (Fig. 3).

136 During the earliest sampling, large tracts of contiguous forest consisting of various

137 microhabitats dominated the region and were sampled accordingly (Fig. 3). This broader

138 expanse of forest likely provided habitat to more species than the current distribution of

139 forest. This increased detection probabilities for some species such as Schiffornis

140 turdina, which was rare even during our earliest sampling. Two general types of forest

141 were present after fragmentation: primary forest and acahual (second growth). Because

142 our sampling was forest-oriented, our efforts tracked the distribution of these habitats.

143 Primary rainforest and second growth habitats were sampled in all efforts. We were

144 unable to separate capture data by site for the early sampling periods; our findings

145 therefore include data from the somewhat larger area from the station east to the coast.

146 Our sampling was also uneven with respect to season, with wet and dry season sampling

147 being unevenly distributed among years; we attempt to account for this, especially in

148 relation to seasonal movements, when considering the results. This sampling

149 heterogeneity leads us to be cautious and conservative in our analyses and

150 interpretations. Importantly, however, the same site ( $\left.18^{\circ} 34^{\prime} 50^{\prime \prime} \mathrm{N}, 95^{\circ} 04^{\prime} 20^{\prime \prime} \mathrm{W}\right)$ and net

151 lanes were used in the 1992-2004 efforts (sample periods 4-8 in Table 1).

152 Only resident species were used in our analyses due to seasonal migration and the 
153 high levels of variance in abundance this causes among obligate migrants. Changes in

154 relative abundance were detected by comparing capture rates (birds per 1000 net hours)

155 from each year of sampling. Through visual inspection of data (Appendix) we chose

156 species absent in later samples and those with trends of apparently declining or

157 increasing rates of capture for more detailed analyses. Neither gaps nor monotonic

158 changes were necessary for inclusion, just suggestion of a possible trend. We did this

159 instead of applying statistical tests across all 122 species to minimize Type I and Type II

160 errors either by applying a very large number of tests or a conservative correction (e.g.,

161 Bonferroni). Presence/absence patterns and observational data (daily checklists in later

162 years) were also considered to provide insight into changes in abundance in low-density

163 species that did not have sufficient samples for statistical testing. Species were

164 considered for examination for presence/absence if they had not been captured since at

165 least 1986-87. Vagrants, defined as those rarely encountered species whose ranges do

166 not normally include the Sierra de Los Tuxtlas, were excluded (Winker et al., 1992;

167 Howell \& Webb, 1995). Only first-time captures (within a season) were used in statistical

168 analyses. Ordinary least squares regression was used to detect changes in abundance for

169 selected species. We looked for newly appearing species using presence/absence netting,

170 observational, and specimen data. Daily checklists were used to augment mist-net data

171 as a check to determine whether absence from the mist-net data was indicative of reality.

172 Species showing statistically significant declines and those not captured or

173 observed in later sampling periods were categorized by preferred habitat (edge, forest, or

174 semi-open), food preference (fruit/nectar or insects), elevational range, and whether Los

175 Tuxtlas was at the periphery or core of its geographic range (Howell \& Webb, 1995).

176 These characteristics were used to assess whether certain traits of the species increased

177 their vulnerability to local extirpation. 


\section{RESULTS}

During this study we accumulated 165,083 net hours, equivalent to 37.7 net years

180 if netting with a single net occurred twelve hours per day (Table 1). A species

181 accumulation curve for a representative year (1992) with below-average net hours

$182(12,605 ;$ mean $=20,220)$ showed that the avifauna was effectively fully sampled during

183 most field seasons (Fig. S2, though in documenting a species' absence it is the among-

184 season, aggregate sampling that is important). In total, 122 nonmigratory species were

185 captured (Appendix).

Seven species showed statistically significant declines during the sampling period:

Phaethornis striigularis, Xenops minutus, Glyphorynchus spirurus, Onychorhynchus

coronatus, Myiobius sulphureipygius, Henicorhina leucosticta, and Eucometis

penicillata (Table 2). Of these taxa, four were captured throughout the sampling period:

P. striigularis, X. minutus, E. penicillata, and H. leucosticta. G. spirurus was last

captured in 1975, O. coronatus in 1986, and $M$. sulphureipygius in 1994, the last season

of autumn netting. Four other species were captured in substantial numbers during early sampling periods but were not captured in later years: Lepidocolaptes souleyetii,

Ornithion semiflavum, Leptopogon amaurocephalus, and Coereba flaveola (the latter

may be an intratropical migrant in this region; Ramos, 1983); however, these species

failed to show statistically significant declines in linear regression analyses, perhaps due

to nonlinear declines. L. souleyetii was last captured in 1993-94, and the others were last captured in 1994-95. One species, Hylomanes momotula, was captured from 1986-1995 but not in the 1970 s or in 2003-04. Though there were no captures in the 1970s, one individual was collected on 17 May 1974 a few km northeast of the station. A similar pattern occurred in Anabacerthia variegaticeps, with captures occurring only in the 1990s. Only two species (Trogon collaris and Xiphorhynchus flavigaster) showed 
203 significant increases during the study period.

204 Presence/absence mist-net capture data for low-density species not captured after

205 1986-87 could be interpreted as suggesting that an additional 23 taxa were extirpated

206 during the study (Table 3). However, we know from observational data that not all of

207 these species were absent. These taxa included rarely captured species that are too large

208 for effective mist-net capture or that prefer the forest canopy (e.g., Micrastur ruficollis,

209 Cotinga amabilis), mixed/open habitat specialists (e.g., Thraupis abbas and T.

210 episcopus), a small-stream specialist (Chloroceryle aenea), and highland species (e.g.,

211 Myadestes unicolor) that are either not prone to capture in mist nets or at our site.

212 Species such as Tityra inquisitor, both Thraupis tanagers, and others were known to be

213 present on the site or nearby but were not captured in later sampling periods. Four

214 species of hummingbirds are included in Table 3, but due to inconsistent capture

215 probabilities of low-density hummingbird species and non-definitive observational data

216 with respect to accurate identification, we provide no hypotheses regarding their

217 possible extirpation or persistence at the site; further work focusing on these species is

218 warranted. There were six other species not in Tables 2 or 3 in which mist net data alone

219 might suggest declines or absences (Appendix) during the entire study but which were

220 present throughout from observational data; netting is not an effective sampling tool for

221 these taxa because of body size or forest stratum occupied (e.g., Glaucidium

222 brasilianum, Ciccaba virgata, and Celeus castaneus) or because forest understory is not

223 preferred habitat (e.g., Pitangus sulphuratus, Myiozetetes similis, and Volatinia

224 jacarina; Appendix). The first three of these species require more focused study to

225 determine abundances and possible declines.

226 Four lower-density species have likely been extirpated: Taraba major,

227 Formicarius analis, Grallaria guatimalensis, and Schiffornis turdina (Table 3). One 
228 low-density species that might seem to have been extirpated from our data, Elaenia

229 flavogaster, is likely an intratropical migrant here (pers. obs.; Howell \& Webb, 1995;

230 Table 3). Several species were captured only in later sampling periods (Appendix) but

231 were observed or collected throughout, suggesting that there were no additions to the

232 biological station's resident avifauna during the study.

233 Based on all available data during the study (netting and observational data), a

234 minimum of 11 species of birds appear to have been extirpated from the biological

235 station over the past three decades. This translates into an average loss of 3.7 species per

236 decade or a local loss of $2.0 \%$ of the entire Los Tuxtlas avifauna (561 spp.; Schaldach \&

237 Escalante, 1997), 4.1\% of the resident avifauna (269 spp.; Schaldach \& Escalante, 1997),

238 or $9.0 \%$ of the resident species captured in our study (122 spp.; Appendix). All 16 species

239 showing significant declines or no longer present on the site prefer some degree of forest

240 cover (Table 4). Three species are edge specialists: O. semiflavum, O. mexicanus, and $C$.

241 flaveola. Eleven prefer closed canopy forest: P. striigularis, H. momotula, X. minutus,

242 G. spirurus, F. analis, G. guatimalensis, L. amaurocephalus, M. sulphureipygius, S.

243 turdina, H. leucosticta, and E. penicillata. T. major prefers primary forest edge, second

244 growth, and riparian thickets, while $L$. souleyetii prefers semi-open or partly cleared

245 forest.

246 Eleven of 16 , or $68.8 \%$, of the species showing declines or extirpations in this

247 study are insectivores, whereas among all species captured $41 \%$ are insectivores. This

248 trend was not significant, however ( $G$-test with Williams' correction, $P>0.1$ ).

249 The Sierra de Los Tuxtlas is the northernmost limit of the ranges of 13 of the 16

250 species showing declines. G. guatimalensis and H. leucosticta are the only species with a

251 distribution extending substantially to the north and west of the study site. The field site

252 is well within the elevational limits for all 16 species (Table 4). 
The two species that significantly increased in abundance over the sample period

254 (Table 4) both occur here at the core of their ranges, elevational distributions, and in

255 their preferred forest habitat. T. collaris is a frugivore, and X. flavigaster is an

256 insectivore.

257 DISCUSSION

258 Although the absence of a species is not a clear indication of extirpation, our

259 sampling effort, despite its heterogeneity, does suggest that at minimum a species'

260 absence indicates a decline. It is possible that some of the species now apparently gone

261 from the station may persist in other, unsampled fragments. If the data presented here

262 and our interpretations of them are accurate, the extirpation of species from the

263 Estación de Biología Los Tuxtlas has been ongoing since its isolation. Such an

264 "extinction debt" is a recognized component of deforestation, and models of empirical

265 data show that in birds this occurs across decades, but the species affected and the

266 mechanisms of species loss remain poorly understood (Tilman et al., 1994; Ewers \&

267 Didham, 2003, Robinson \& Sherry, 2012). Since 1973, 16 species susceptible to capture

268 in mist nets have either become locally extirpated or are showing significant declines in

269 abundance. The total number of losses and declines is undoubtedly higher than

270 presented, because species not regularly captured in mist nets, such as large-bodied and

271 canopy species, were not adequately surveyed. Species known to have been extirpated

272 from Los Tuxtlas include Sarcoramphus papa, Harpia harpyja, and Ara macao. Patten,

273 Gómez de Silva, \& Smith-Patten (2010) also documented the extirpation of the latter two

274 in Chiapas, Mexico. Many additional species have also been categorized as endangered

275 or threatened in the Sierra de Los Tuxtlas (see Winker, 1997).

276 Our estimate of the average rate of avian losses from the station of 3.7 species per

277 decade may not be directly comparable to other studies due to differences in habitat and 
sampling, but it is similar to the rate of loss observed at Barro Colorado Island by

279 Robinson (1999) of 3.3 species per decade. Our estimate, however, includes only those

280 taxa captured in mist nets, whereas Robinson's work included all species detected

281 through observation.

282 Of the eight species with data sufficient for statistical analysis that showed local

283 extirpation, six were lost between 1992 and 2004 (on the same site), suggesting a

284 continuing extirpation of species from the station. Bierregaard \& Lovejoy $(1988,1989)$

285 found that as surrounding habitat was lost, species richness in remaining fragments

286 increased as individuals displaced from surrounding areas found their way to remaining

287 forest patches. This increased richness was limited by the lifespan of the individual birds

288 (Bierregaard \& Lovejoy 1988, 1989). Unlike these studies, in which forest patches were

289 suddenly and completely isolated, the forest of the Estación de Biología Los Tuxtlas was

290 isolated gradually. Because extirpation seems to be continuing, we expect declines and

291 extirpations to continue for some time at the station, even if no further deforestation

292 occurs in the region (Willis, 1974; Brooks, Pimm, \& Oyugi, 1999, Robinson, 1999; Ferraz

293 et al., 2003).

$294 \quad$ Mechanisms for tropical bird species losses due to deforestation and

295 fragmentation probably include factors such as greater specialization as compared to

296 temperate birds, reduced dispersal abilities, lower population densities, and patchy

297 distributions (Robinson et al., 2004; Stratford \& Robinson, 2005; Moore et al., 2008;

298 Rompré et al., 2007). Our assessment of possible causes for the loss of these species

299 reveals no definite patterns, however, other than the predominant requirement of

300 forested habitat. On Barro Colorado Island in Lake Gatún, Panama, maturation of

301 habitat and loss of open areas was responsible for the decline in the island's avifauna

302 (Willis, 1974; Karr, 1982). This is unlikely to be the case in Los Tuxtlas. Despite major 
303 degradation of surrounding forests, the station has remained primary forest with areas

304 of second growth. A loss of sapling and seedling species has been described (Dirzo \&

305 Miranda, 1990), but the overall structure of the forest appears to have remained fairly

306 stable. Vetter et al. (2011) found in a meta-analysis of 30 studies that the effects of

307 fragmentation are not subject to simple generalities, and that they are highly site

308 specific. Patten \& Smith-Patten (2011) pointed to the need to understand extirpations at

309 local scales because responses can differ from predictions made at larger scales.

310 Los Tuxtlas is at the northernmost extent of the ranges of 13 of the 16 species we

311 found to be declining or extirpated (Tables 3 and 4). Evidence is mixed as to whether

312 populations at the periphery of a species' range are more vulnerable to extirpation

313 (Terborgh \& Winter, 1980; Kattan, Halvarez-Lopez, \& Giraldo, 1994; Johnson, 1998).

314 Los Tuxtlas is at the edge of all species' geographic ranges endemic to Neotropical

315 rainforest, so it is not clear why this subset might be more subject to this phenomenon.

316 The elevational distribution of each of these species encompasses sea level to $750 \mathrm{~m}$ or

317 more (Howell \& Webb, 1995), and we consider this factor unlikely to be responsible for

318 the vulnerability of these particular taxa.

319 Although insectivores showed a trend toward being disproportionately affected in

320 our study, it was not significant. Elsewhere insectivores have been shown to be

321 particularly vulnerable to severe habitat change (e.g., Kattan, Halvarez-Lopez, \& Giraldo,

322 1994; Canaday, 1996; Johnson \& Winker, 2010; Vetter et al., 2011). Additionally,

323 deforestation can negatively impact species found in multi-species foraging flocks (Van

324 Houtan et al., 2006), which are important to many birds of tropical rainforest

325 communities (Willis, 1966; Morton, 1973; Buskirk, 1976; Rappole et al., 1983). Rappole

326 \& Morton (1985) noted that $X$. minutus, one of the species showing a significant decline

327 in our study (Table 2) was a regular member of mixed flocks in the Sierra de Los Tuxtlas. 
We considered large-scale range shifts, perhaps from climate change, as a

329 possible cause for species loss, but this seems unlikely. At least some of the species lost

330 in our study appear to have persisted in the southern portion of Los Tuxtlas near Volcán

331 Santa Marta at least into the mid-1990s (Winker, pers. obs.). If range shifts were the

332 cause, species would likely have disappeared region-wide and we would not expect only

333 forest-related species to be affected. Habitat loss and degradation seem to be the best

334 explanations for the losses observed, but exactly how these changes affected each species

335 remains unknown.

336 Another possible influence on mist-net captures, particularly in the most recent,

337 late winter/spring sampling periods, would be seasonal intra-tropical and elevational

338 movements in some of the study species (Ramos, 1983, 1988). There is evidence that $C$.

339 flaveola and E. flavogaster move seasonally within the tropics, seemingly to breed in

340 Los Tuxtlas then departing (Ramos \& Rappole, pers. obs.). Vega Rivera (1982) found

341 probable elevational movements in M. sulphureipygius. The extirpations of seven of the

34216 species are particularly notable. C. flaveola is a widely distributed species known to

343 thrive in manipulated habitats such as gardens and forest edges and is a generalist

344 frugivore and nectarivore (pers. obs.; Howell \& Webb, 1995). This is not a species we

345 would expect to decline due to forest fragmentation; both its habitat and food

346 preferences are well suited to survival in a mosaic landscape, and it is known to persist in

347 a fragmented landscape elsewhere in northern Middle America (Johnson \& Winker,

348 2010). Intratropical migrations of $C$. flaveola may partially explain the changing capture

349 rates in this species (Ramos \& Rappole, pers. obs.). O. semiflavum and $L$.

350 amaurocephalus are both edge specialists; thus, limited fragmentation, creating an

351 increase in edges, might a priori seem to benefit these species. Though the habitat

352 protected by the station has remained relatively static, the intensity of lowland 
353 deforestation in Los Tuxtlas as a whole (Fig. 1) may be too extensive even for these edge

354 specialists. L. souleyetii prefers open forest and partially cleared areas (Howell \& Webb,

355 1995). The habitat surrounding the station during the 1980 s and 1990 s was dominated

356 by pasture scattered with isolated trees. In our later field seasons there was a noticeable

357 decline in the number of isolated trees and fences constructed of living trees (Winker,

358 pers. obs.). This loss may account for the extirpation of L. souleyetii. G. spirurus

359 apparently disappeared from the station between the 1970 s and 1986, the first of the

360 documented extirpations. The majority of deforestation across the region took place

361 during this period. This previously abundant species disappeared from our data in just

362 over a decade. Interestingly, on the slopes of neighboring Volcán Santa Marta the species

363 was present at least into the 1990 and probably still persists there (Winker, pers. obs.).

364 Also, Estrada, Coates-Estrada, \& Merritt (1997) had observational data of the species'

365 presence in the station area in 1990-1992, indicating at least a decline if not extirpation

366 (Table 2). In Brazil, G. spirurus persisted in experimentally isolated fragments well after

367 isolation (Stouffer \& Bierregaard 1995), and the species persists in highly fragmented

368 forest in southern Belize (Johnson \& Winker, 2010). H. momotula was collected but not

369 netted in 1974, was captured in substantial numbers during 1986 and 1992-94, but was

370 absent in the last two seasons of sampling. This pattern is mysterious. This species has

371 an elevational range extending to $1500 \mathrm{~m}$ and may persist in the forests of the upper

372 slopes of Volcán San Martín. If so, we speculate that the station may serve as a sink for

373 this species, where habitat is insufficient for a self-sustaining population but may

374 occasionally be colonized by dispersing individuals (see also Winker et al., 1997).

375 Continued sampling may provide more insight into its abundance patterns. It illustrates

376 the need for improved understanding of species-specific dispersal behavior within and

377 among forest fragments (e.g., Van Houtan et al., 2007; Moore et al., 2008; Ibarra- 
378 Macias, Robinson, \& Gaines 2011), which may be an important driver for patterns such

379 as those we observed.

380 Two other studies provide comparative value to our results. The four species we 381 consider likely extirpated (Taraba major, Formicarius analis, Grallaria guatimalensis,

382 and Schiffornis turdina) were not detected in the much broader census surveys of

383 Estrada, Coates-Estrada, \& Merritt (1997) in 1990-1992. Patten, Gómez de Silva, \&

384 Smith-Patten (2010) conducted the geographically closest long-term study to ours in

385 their analysis of avian declines at Palenque, Chiapas, Mexico. Their results showed only

386 three species that overlapped our results. They found Eucometis penicillata extirpated

387 (to our decline) and two others that declined as our populations did (Xenops minutus

388 and Leptopogon amaurocephalus). Indeed, the species-level heterogeneity between our

389 studies is noteworthy. A key similarity between our studies, however, is the importance

390 of forest in explaining declines and extripations (Patten \& Smith-Patten, 2011).

391 Our analyses suggest that the Estación de Biología Tropical Los Tuxtlas is too

392 small to maintain its full, historic complement of bird species. If deforestation

393 accelerated region-wide, eliminating other forest refugia, the station alone (640 ha)

394 would be unable to maintain the historical avian diversity of the region or to provide

395 source populations for restored forest habitats for many of its present bird species. Given

396 the scale of deforestation in the region, it is surprising that there are not more species

397 showing declines. Indeed, we may consider it good news that important forest seed

398 dispersers such as Habia tanagers (Puebla \& Winker, 2004) did not show significant

399 declines. The overall size of the remaining forests, particularly in the highlands, may be

400 ameliorating the effects of lowland deforestation. However, increasing or continued

401 isolation of the station will probably limit recolonization from elsewhere, and species

402 losses will likely continue. 
In our study, although several species seemed to quickly succumb to local and

404

405

406

407

408

409

410

411

412

413

414

415

416

417

418

419

420

421

422

423

424

425

426

427

regional deforestation, others showed delayed declines and extirpations, a phenomenon

also known to happen at larger scales (Tilman et al., 1994, Pimm et al., 2006). Moreover, the effects of deforestation were remarkably heterogeneous among forest-related species, with no single clear pattern of why some species experienced declines or extirpation. Our long-term data suggest that predicting which species will be most affected by deforestation in the northern Neotropics, and thus effectively working to ameliorate the effects of forest loss, will be particularly challenging. Nevertheless, as similar long-term datasets accrue, subtle patterns may reveal how species-specific responses reflect underlying commonalities that can be exploited for effective management and conservation.

\section{ACKNOWLEDGMENTS}

We thank the many field assistants who have helped us over the years and those who have provided and helped obtain permits to conduct this research. R. Barry, A. Powell, S. Pimm, M. Patten, and three anonymous reviewers provided excellent advice and comments.

\section{LITERATURE CITED}

Andrén H. 1994. Effects of habitat fragmentation on birds and mammals in landscapes with different proportions of suitable habitat: a review. Oikos 71:355-366.

Andrle RF. 1966. North American migrants in the Sierra de Tuxtla of southern Veracruz, Mexico. Condor 68:177-184.

Barlow J, Peres CA, Henriques LMP, Stouffer PC, Wunderle JM. 2006. The responses of understorey birds to forest fragmentation, logging and wildfires: An Amazonian synthesis. Biological Conservation 128:182-192.

Becker P, Moure JS, Peralta FJA. 1991. More about euglossine bees in 
Amazonian forest fragments. Biotropica 23:586-591.

429 Bierregaard RO, Lovejoy TE. 1988. Birds in Amazonian forest fragments: Effects of 430 insularization. Pages 1564-1579 in: Acta XIX Congressus Internationalis

431 Ornithologici (H. Oellet, ed.). University of Ottawa Press, Ottawa, Canada.

432 Bierregaard RO, Lovejoy TE. 1989. Effects of forest fragmentation on Amazonian

433 understory bird communities. Acta Amazonica 19:215-241.

434 Blake JG. 1991. Nested subsets and the distribution of birds in isolated woodlots.

435 Conservation Biology 5:58-86.

436 Brook BW, Sodhi NS, Ng PKL. 2003. Catastrophic extinctions follow deforestation in

437 Singapore. Nature 424:420-423.

438 Brooks TM, Pimm SL, Oyugi JO. 1999. Time lag between deforestation and bird

439 extinction in tropical forest fragments. Conservation Biology 13:1140-1150.

440 Buskirk WH. 1976. Social systems in a tropical forest avifauna. American Naturalist

$441 \quad 110: 293-310$.

442 Canaday C. 1996. Loss of insectivorous birds among a gradient of human impact in

$443 \quad$ Amazonia. Biological Conservation 77:63-77.

444 Ceballos G, Ehrlich PR. 2002. Mammal population losses and the extinction crisis.

$445 \quad$ Science 296:904-907.

446 Daily GC, Ehrlich PR. 1995. Preservation of biodiversity in small rainforest patches: rapid evaluations using butterfly trapping. Biodiversity and Conservation 4: 35-55.

449 Dirzo R, Garcia MC. 1992. Rates of deforestation in Los Tuxtlas, a Neotropical area in southeast Mexico. Conservation Biology 6:84-90.

451 Dirzo R, Miranda A. 1990. Contemporary Neotropical defaunation and forest structure, 452 function, and diversity, a sequel to John Terborgh. Conservation Biology 4:444- 
454 Dirzo R, Miranda A. 1991. Altered patterns of herbivory and diversity in the forest understory: a case study of the possible consequences of contemporary defaunation. Pages 273-287 in: Plant-Animal Interactions: Evolutionary ecology

Dirzo R, Raven PH. 2003. Global state of biodiversity and loss. Annual Review of Environment and Resources 28:137-167. to fragmentation. Biological Reviews 81:117-142.

Faaborg J, Brittingham M, Donovan T, Blake J. 1995. Habitat fragmentation in the temperate zone. Pages 357-380 in: Ecology and management of Neotropical migratory birds: a synthesis and review of the critical issues (Finch DM, Martin

Estrada A, Coates-Estrada R, Merritt Jr DA. 1997. Anthropogenic landscape changes and avian diversity at Los Tuxtlas, Mexico. Biodiversity and Conservation 6:19-43.

Ewers RM, Didham RK. 2006. Confounding factors in the detection of species responses TE, eds.). Oxford University Press, Cambridge, United Kingdom.

Fahrig L. 2003. Effects of habitat fragmentation on biodiversity. Annual Review of Ecology Evolution and Systematics 34:487-515.

Ferraz G, Russell GJ, Stouffer PC, Bierregaard RO, Pimm SL, Lovejoy TE. 2003. Rates of species loss from Amazonian forest fragments. Proceedings of the National Academy of Sciences USA 100:14069-14073.

Ferraz G, Nichols JD, Hines JE, Stouffer PC, Bierregaard RO, Lovejoy TE. 2007. A largescale deforestation experiment: Effects of patch area and isolation on Amazon

477 González-Soriano E, Dirzo R, Vogt RC, eds. 1997. Historia Natural de Los Tuxtlas. 
Universidad Nacional Autónoma de México, México, D.F.

479 Howell S, Webb S. 1995. A guide to the birds of Mexico and northern Central America.

$480 \quad$ Oxford University Press, New York.

481 Ibarra-Macias A, Robinson WD, Gaines MS. 2011. Experimental evaluation of bird

482 movements in a fragmented Neotropical landscape. Biological Conservation

$483 \quad 144: 703-712$.

484 Ibarra-Manríquez G, Martinez-Ramos M, Dirzon R, Núñez-Farfán J. 1997 La vegetación. 485 Pages 61-74 in Historia Natural de Los Tuxtlas (González-Soriano E, Dirzo R, 486 Vogt RC, Eds). Universidad Nacional Autónoma de México, México, D.F.

487 Johnson AB, Winker K. 2010. Short-term hurricane impacts on a Neotropical $488 \quad$ community of marked birds. PLOS ONE 5:e15109.

489 Johnson CN. 1998. Species extinction and the relationship between distribution and $490 \quad$ abundance. Nature 394:272-274.

491 Kattan GH, Halvarez-Lopez H, Giraldo M. 1994. Forest fragmentation and bird 492 extinctions: San Antonio eighty years later. Conservation Biology 8:138-146.

493 Karr JR. 1982. Population variability and extinction in a tropical land-bridge island. 494 Ecology 63:1975-1978.

495 Laurance WF, et al. 2011. The fate of Amazonian forest fragments: A 32-year

496 investigation. Biological Conservation 144:56-67.

497 Leck CF. 1979. Avian extinctions in an isolated tropical wet-forest preserve, Ecuador. $498 \quad$ Auk 96:343-352.

499 Lees AC, Peres CA. 2006. Rapid avifaunal collapse along the Amazonian deforestation $500 \quad$ frontier. Biological Conservation 133:198-211.

501 Leigh EG, Jr. 1975. Population fluctuations, community stability, and environmental 502 variability. Pages 52-73 in: Ecology and evolution of communities (Cody ML, 
Diamond JM, eds.). Belknap Press, Cambridge, Massachusetts.

504 Leigh EG, Jr. 1981. The average lifetime of a population in a varying environment.

$505 \quad$ Journal of Theoretical Biology 90:213-239.

506 Lovejoy TE, Rankin JM, Bierregaard RO, Brown KS, Jr., Emmons LH, Van Der Voort

507

508

509

Lovejoy TE, Bierregaard RO, Rylands AB, Malcolm JR, Quintela CE, Harper LH, Brown

510

KS, Powell AH, Powell GVN, Schubart HOR, Hays MB. 1986. Edge and other

511

512

513

ME. 1984. Ecosystem decay of Amazon forest remnants. Pages 295-325 in:

Extinctions (Nitecki MH, ed.). University of Chicago Press, Chicago, Illinois. effects of isolation on Amazon forest fragments. Pages 257-285 in: Conservation biology: The science of scarcity of diversity (Soule ME, ed.). Sinauer Associates, Sunderland, Massachusetts.

Malcolm JR. 1988. Small mammal abundances in isolated and non-isolated primary forest reserves near Manaus, Brazil. Acta Amazonica 18: 67-83.

514 Mendoza E, Fay J, Dirzo R. 2005. A quantitative analysis of forest fragmentation in Los

515 Tuxtlas, southeast Mexico: patterns and implications for conservation. Revista

$516 \quad$ Chilena de Historia Natural 78:451-467.

517 Moore RP, Robinson WD, Lovette IJ, Robinson TR. 2008. Experimental evidence for

518 extreme dispersal limitation in tropical forest birds. Ecology Letters 11: 960-968.

519 Morton ES. 1973. On the evolutionary advantages and disadvantages of fruit eating in $520 \quad$ tropical birds. American Naturalist 107:8-22.

521 Nemark WD. 1991. Tropical forest fragmentation and the local extinction of understory

522 birds in the eastern Usambara Mountains, Tanzania. Conservation Biology 5:67$523 \quad 78$.

524 O'Grady JJ, Reed DH, Brook BW, Frankham R. 2004. What are the best correlates of 525 predicted extinction risk? Biological Conservation 118:513-520. 
526 Pahl LI, Winter JW, Heinsohn G. 1988. Variation in responses of arboreal marsupials to

527 fragmentation of tropical rainforest in north eastern Australia. Biological

$528 \quad$ Conservation $46: 71-82$

529 Patten MA, Gomez de Silva H, Smith-Patten BD. 2010. Long-term changes in the bird

530 community of Palenque, Chiapas, in response to rainforest loss. Biodiversity and

$531 \quad$ Conservation 19:21-36.

532 Patten MA, Smith-Patten BD. 2011. Predictors of occupancy trend across spatial scale.

$533 \quad$ Conservation Biology 6:1203-1211.

534 Pennington TD, Sarukhan J. 1968. Arboles Tropicales de Mexico. Instituto Nacional de

535 Investigacciones Forestales, D.F., Mexico.

536 Pimm SL, Jones HH, Diamond J. 1988. On the risk of extinction. American Naturalist $537 \quad 132: 757-785$.

538 Pimm SL, Raven P, Peterson A, Şekercioğlu Ç, Ehrlich PR. 2006. Human impacts on the 539 rates of recent, present, and future bird extinctions. Proceedings of the National $540 \quad$ Academy of Sciences USA 103:10941-10946.

541 Powell AH, Powell GVN. 1987. Population dynamics of male euglossine bees in 542 Amazonian forest fragments. Biotropica 19: 176-179.

543 Puebla F, Winker K. 2004. Dieta y dispersión de semillas de dos especies de tangara 544 (Habia) en dos tipos de vegetación en Los Tuxtlas, Veracruz, México. Ornitología $545 \quad$ Neotropical 15:53-64.

546 Ramos MA. 1983. Seasonal movements of bird populations at a Neotropical study site

547 in southern Veracruz, Mexico. Ph.D. dissertation. University of Minnesota, $548 \quad$ Minneapolis.

549 Ramos MA. 1988. Eco-evolutionary aspects of bird movements in the northern 550 Neotropical region. Pages 251-293 in: Acta XIX Congressus Internationalis 

Canada.

553 Rappole JH, Warner DW. 1980. Ecological aspects of migrant bird behavior in Veracruz,

Robinson WD, Sherry TW. 2012. Mechanisms of avian population decline and species

Robinson WD. 1999. Long-term changes in the avifauna of Barro Colorado piedmont of the mid-Atlantic region. Atlantic Naturalist 33:31-36.

Robbins CS. 1980. Effect of forest fragmentation on breeding bird populations in the abundance in bird populations. Auk 113: 381-398.

Rappole JH, Morton ES, Lovejoy TE, III, Ruos JL. 1983. Nearctic avian migrants in the Neotropics. United States Fish and Wildlife Service, Washington D.C.

Rappole JH, Powell GVN, Sader SA. 1994. Remote-sensing assessment of tropical habitat availability for a Nearctic migrant: the Wood Thrush. Pages 91-103 in: Mapping the diversity of nature (Miller RI, ed.). Chapman and Hall, London.

Rappole JH, Winker K, Powell GVN. 1998. Migratory bird habitat use in southern Mexico: mist nets versus point counts. Journal of Field Ornithology 69:635-643.

Remsen JV Jr., Good DA. 1996. Misuse of data from mist-net captures to assess relative Island, Panama, a tropical forest isolate. Conservation Biology 13:85-97.

575 Rolstad J. 1991. Consequences of forest fragmentation for the dynamics of bird 
populations: conceptual issues and the evidence. Biological Journal of the Linnean Society 42:149-163.

578 Rompré G, Robinson WD, Desrochers A, Angehr G. 2007. Environmental correlates of avian diversity in lowland Panama rainforests. Journal of Biogeography 34:802815.

Schaldach W, Escalante P. 1997. Lista de Aves. Pages 571-573 in: Historia Natural de Los Tuxtlas (González-Soriano E, Dirzo R, Vogt RC, eds.). Universidad Nacional Autonoma de Mexico. D.F., Mexico.

Stotz DF, Fitzpatrick JW, Parker TA, Moskovits DK. 1996. Neotropical birds: ecology and conservation. University of Chicago Press, Chicago.

Stouffer PC, Bierregaard RO. 1995. Effects of forest fragmentation on understory

Stratford JA, Robinson WD. 2005. Gulliver travels to the fragmented tropics: geographic variation in mechanisms of avian extinction. Frontiers in Ecology and the

Stuart SN, Chanson JS, Cox NA, Young BE, Rodrigues ASL, Fischman DL, Waller RW. Environment 3:85-92. 2004. Status and trends of amphibian declines and extinctions worldwide.

Terborgh J, Winter B. 1980. Some causes of extinction. Pages 119-133 In: Conservation 600 biology: an evolutionary-ecological perspective (Soule ME, Wilcox BA, eds.). 
Sinauer Associates, Sunderland, Massachusetts.

602 Tilman D, May RM, Lehman CL, Nowak MA. 1994. Habitat destruction and the 603 extinction debt. Nature 371:65-66.

604 Turner IM. 1996. Species loss in fragments of tropical rain forest: a review of the 605 evidence. Journal of Applied Ecology 33:200-209.

606 Van Houtan KS, Pimm SL, Bierregaard RO, Jr., Lovejoy TE, Stouffer PC. 2006. Local extinctions in flocking birds in Amazonian forest fragments. Evolutionary Ecology Research 8:129-148.

Van Houtan KS, Pimm SL, Halley JM, Bierregaard RO Jr., Lovejoy TE. 2007. Dispersal of Amazonian birds in continuous and fragmented forest. Ecology Letters 10:219229.

612 Vega Rivera JH. 1982. Aspectos biologicos de Myiobius sulphureipygius (Aves: Tyrannidae) en el area de Santa Marta region de “Los Tuxtlas,” Veracruz, Mexico.

615 Vetter D, Hansbauer MM, Végvári Z, Storch I. 2011. Predictors of forest fragmentation 616 sensitivity in Neotropical vertebrates: a quantitative review. Ecography 34:1-8.

617 Whitman AA, Hagan JM III, Brokaw NVL. 1997. A comparison of two survey techniques $618 \quad$ used in a subtropical forest. Condor 99:955-965.

619 Willis EO. 1966. The role of migrant birds at swarms of army ants. Living Bird 5:187620231.

621 Willis EO. 1974. Populations and local extinctions of birds on Barro Colorado Island, 622 Panama. Ecological Monographs 44:153-169.

623 Willis EO. 1979. The composition of avian communities in remanescent woodlots in $624 \quad$ southern Brazil. Papeis Avulsos de Zoolgia 33:1-25.

625 Winker K. 1995. Habitat selection in woodland Nearctic-Neotropic migrants on the 
627 Winker K. 1997. Introduction to the birds of Los Tuxtlas. Pages 535-541 in: Historia $628 \quad$ Natural de Los Tuxtlas (González-Soriano E, Dirzo R, Vogt RC, Eds.). $629 \quad$ Universidad Nacional Autonoma de Mexico. D.F., Mexico.

630 Winker K, Rappole JH, Ramos MA. 1990. Population dynamics of the Wood Thrush

631 (Hylocichla mustelina) on its wintering grounds in southern Veracruz, Mexico. $632 \quad$ Condor 92:444-460.

633 Winker K, Oehlenschlager RJ, Ramos MA, Zink RM, Rappole JH, Warner DW. 1992. 634 Avian distribution and abundance records for the Sierra de Los Tuxtlas, Veracruz, $635 \quad$ Mexico. Wilson Bulletin 104:699-718.

636 Winker K, Escalante P, Rappole JH, Ramos MA, Oehlenschlager RJ, Warner DW. 1997. 637 Periodic migration and lowland forest refugia in a sedentary Neotropical bird, $638 \quad$ Wetmore's bush-tanager. Conservation Biology 11:692-697.

639 Zimmerman BL, Bierregaard RO. 1986. Relevance of the equilibrium theory of 640 island biogeography and species-area relations to conservation with a case from 641 Amazonia. Journal of Biogeography 13:133-143. 


\section{Figure captions}

644 Figure 1. Comparative views of the Sierra de Los Tuxtlas from an artificially colorized 6451979 Landsat image (top) and a 2010/11 Google Earth image (bottom) showing the 646 extent of deforestation in the region. Remaining forest has become concentrated at 647 higher elevations on the slopes of the region's three volcanoes, San Martín, Santa Marta, 648 and San Martín Pajápan (the forested areas remaining, from left to right).

650 Figure 2. Satellite view of Volcán San Martín, the northernmost volcano in the Sierra de 651 Los Tuxtlas, showing the distribution of forests (dark areas). The study area is indicated 652 by the white box, which corresponds to the area in Fig. 3 (image from Google Earth, 653 2010).

655 Figure 3. Maps of the study area in the northern lowlands of the Sierra de Los Tuxtlas 656 (this is the area in the white box in Fig. 2) showing a rough outline of all forests types 657 (dark gray areas) in 1979 (top, from Landsat image), in 2005 (bottom, from 658 GoogleEarth), and netting sites (black polygons). Numbers indicate field season(s) site 659 was used and correspond to rows in Table 1.

661 Figure S1. A series of satellite images depicting deforestation in Los Tuxtlas, focusing in 662 on the volcanoes Santa Marta (left) and San Martín Pajápan (right), starting with a 663 1973/4 Skylab image (upper left) and progressing through a series of Landsat images, 664 from 1999 (upper right), 2003 (lower left), and 2011 (lower right).

666 Figure S2. Species accumulation curve for a representative year with below average net 
667 hours (1992, 12,605 net hours). 


\section{Table 1 (on next page)}

Sample effort and periods during eight nonbreeding seasons across three decades in the Sierra de Los Tuxtlas, Veracruz, Mexico.

Sample effort and periods during eight nonbreeding seasons across three decades in the Sierra de Los Tuxtlas, Veracruz, Mexico. 
2 Table 1. Sample effort and periods during eight nonbreeding seasons across three

3 decades in the Sierra de Los Tuxtlas, Veracruz, Mexico.

\begin{tabular}{lcc}
\hline $\begin{array}{l}\text { Nonbreeding } \\
\text { season }\end{array}$ & Net & $\begin{array}{c}\text { Sampling } \\
\text { hours }\end{array}$ \\
\hline 1) 1973-74 & 33,976 & 15 Aug-26 May \\
2) 1974-75 & 36,512 & 7 Aug-29 May \\
3) 1986-87 & 4,310 & 17 Nov-16 Jan \\
4) 1992-93 & 12,605 & 5 Sep-15 Nov \\
5) 1993-94 & 41,142 & 25 Aug-20 May \\
6) 1994-95 & 22,509 & 15 Aug-15 Nov \\
7) 2002-03 & 8,395 & 21 Feb-27 Apr \\
8) 2003-04 & 2,312 & 5 Apr-29 Apr \\
\hline
\end{tabular}




\section{Table 2 (on next page)}

Outcomes of regression analyses for 14 species showing changes in abundance (capture rates; captures and rates are given in the Appendix) and those not detected in the later sampling periods. Those $\mathrm{P}$-values presented in bold are significant at alpha $=$ 0.0

Outcomes of regression analyses for 14 species showing changes in abundance (capture rates; captures and rates are given in the Appendix) and those not detected in the later sampling periods. Those P-values presented in bold are significant at alpha $=0.05$. 
1 Table 2. Outcomes of regression analyses for 14 species showing changes in abundance

2 (capture rates; captures and rates are given in the Appendix) and those not detected in

3 the later sampling periods. Those $P$-values presented in bold are significant at $\alpha=0.05$.

\begin{tabular}{|c|c|c|c|c|}
\hline Species & $F$ & $P$ & $R^{2}$ & Last captured \\
\hline Phaethornis striigularis ${ }^{c}$ & 6.337 & 0.045 & 0.514 & $2002-03$ \\
\hline Hylomanes momotula ${ }^{a}$ & 0.210 & 0.890 & 0.003 & 1994-95 \\
\hline Trogon collaris ${ }^{b}$ & 7.041 & 0.038 & 0.540 & $\mathrm{n} / \mathrm{a}$ \\
\hline Xiphorhynchus flavigaster $^{b}$ & 6.941 & 0.039 & 0.536 & $\mathrm{n} / \mathrm{a}$ \\
\hline Xenops minutus ${ }^{c}$ & 7.578 & 0.033 & 0.558 & 2003-04 \\
\hline Glyphorynchus spirurus ${ }^{c, d}$ & 7.529 & 0.034 & 0.557 & $1974-75$ \\
\hline Lepidocolaptes souleyetii ${ }^{d}$ & 3.265 & 0.121 & 0.352 & $1992-93$ \\
\hline Ornithion semiflavum ${ }^{d}$ & 0.327 & 0.588 & 0.052 & 1994-95 \\
\hline Leptopogon amaurocephalus ${ }^{d}$ & 2.814 & 0.144 & 0.319 & 1994-95 \\
\hline Onychorhynchus coronatus ${ }^{c, d}$ & 6.861 & 0.040 & 0.533 & $1986-87$ \\
\hline Myiobius sulphureipygius ${ }^{c, d}$ & 10.555 & 0.019 & 0.629 & $1994-95$ \\
\hline Henicorhina leucostictac,d & 6.740 & 0.041 & 0.529 & 2003-04 \\
\hline Coereba flaveolad & 2.164 & 0.192 & 0.265 & 1994-95 \\
\hline Eucometis penicillatac $^{c}$ & 18.725 & 0.005 & 0.757 & $2002-03$ \\
\hline
\end{tabular}

$4 \quad{ }^{a}$ Species captured 1986-1995. See text. 
$5 \quad{ }^{\mathrm{b}}$ Species showing an increase in abundance.

$6 \quad{ }^{\mathrm{c}}$ Species showing a significant decline.

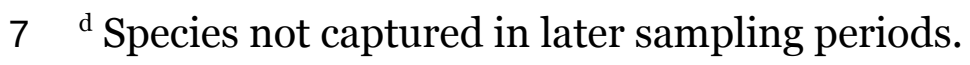




\section{Table 3 (on next page)}

Species not captured or observed from 1992-2004, seasons captured (from Appendix), presence on the field site in later sampling periods, and comments.

Species not captured or observed from 1992-2004, seasons captured (from Appendix), presence on the field site in later sampling periods, and comments. 
1 Table 3. Species not captured or observed from 1992-2004, seasons captured (from

2 Appendix), presence on the field site in later sampling periods, and comments.

\begin{tabular}{|c|c|c|c|}
\hline Species & Seasons Captured & Presence & Comments \\
\hline Micrastur ruficollis & 1 & $\mathrm{Y}$ & observed \\
\hline Crypturellus boucardi & 3 & $\mathrm{Y}$ & observed \\
\hline Heliomaster longirostris & 1 & $?$ & hummingbird \\
\hline Florisuga mellivora & 1 & $?$ & hummingbird \\
\hline Chlorostilibon canivetii & 2 & $?$ & hummingbird \\
\hline Hylocharis eliciae & 1,2 & $?$ & hummingbird \\
\hline Chloroceryle aenea & 1,2 & Y & small streams \\
\hline Dryocopus lineatus & 2 & $\mathrm{Y}$ & observed \\
\hline Synallaxis erythrothorax & 2 & Y & observed \\
\hline Taraba major & 2 & $\mathrm{~N}$ & $\begin{array}{c}\text { forest } \\
\text { understory }\end{array}$ \\
\hline Formicarius analis & 1 & $\mathrm{~N}$ & $\begin{array}{c}\text { forest } \\
\text { understory }\end{array}$ \\
\hline Grallaria guatimalensis & 1,3 & $\mathrm{~N}$ & $\begin{array}{c}\text { forest } \\
\text { understory }\end{array}$ \\
\hline Tityra inquisitor & 1 & $\mathrm{Y}$ & $\begin{array}{c}\text { observed, } \\
\text { canopy }\end{array}$ \\
\hline Cotinga amabilis & 1 & $?$ & canopy \\
\hline Schiffornis turdina & 1 & $\mathrm{~N}$ & $\begin{array}{c}\text { forest } \\
\text { understory }\end{array}$ \\
\hline Polioptila plumbea & 1 & $\mathrm{Y}$ & observed \\
\hline Myadestes unicolor & 1 & $\mathrm{Y}$ & highlands \\
\hline Euphonia affinis & 2 & $?$ & none \\
\hline
\end{tabular}


Thraupis abbas

Thraupis episcopus

Saltator atriceps

Molothrus aeneus
1

2

1,2

1
Y

Y

Y

Y observed

observed

observed

observed 


\section{Table 4 (on next page)}

Habitat, foraging preference, elevational range, and position within geographical distribution for 18 species of birds at the Estación de Biología Los Tuxtlas (from Howell and Webb, 1995).

Habitat, foraging preference, elevational range, and position within geographical distribution for 18 species of birds at the Estación de Biología Los Tuxtlas (from Howell and Webb, 1995). 
1 Table 4. Habitat, foraging preference, elevational range, and position within

2 geographical distribution for 18 species of birds at the Estación de Biología Los Tuxtlas

3 (from Howell and Webb, 1995).

\begin{tabular}{|c|c|c|c|c|}
\hline Species & $\begin{array}{c}\text { Habitat } \\
\text { preference }\end{array}$ & $\begin{array}{l}\text { Foraging } \\
\text { guild }\end{array}$ & $\begin{array}{c}\text { Elevational } \\
\text { distribution }(\mathrm{m})\end{array}$ & $\begin{array}{l}\text { Geographic } \\
\text { distribution }\end{array}$ \\
\hline Phaethornis striigularis & forest & nectarivore & $0-1500$ & periphery \\
\hline Hylomanes momotula & forest & frugivore & $0-1500$ & periphery \\
\hline Trogon collaris & forest & frugivore & $0-2400$ & core \\
\hline Xenops minutus & forest & insectivore & $0-1000$ & periphery \\
\hline Xiphorhynchus flavigaster & forest & insectivore & $0-1500$ & core \\
\hline Glyphorynchus spirurus* & forest & insectivore & $0-1200$ & periphery \\
\hline Lepidocolaptes souleyetii & semi-open & insectivore & $0-1500$ & periphery \\
\hline Taraba major* & forest & insectivore & $0-1600$ & periphery \\
\hline Formicarius analis* & forest & insectivore & $0-750$ & periphery \\
\hline Grallaria guatimalensis* & forest & insectivore & $50-3500$ & core \\
\hline Ornithion semiflavum & edge & insectivore & $0-1500$ & periphery \\
\hline Leptopogon amaurocephalus & edge & insectivore & $0-1300$ & periphery \\
\hline Onychorhynchus coronatus & forest & insectivore & $0-1200$ & periphery \\
\hline Myiobius sulphureipygius & forest & insectivore & $0-1000$ & periphery \\
\hline Schiffornis turdina* & forest & frugivore & $0-750$ & periphery \\
\hline Henicorhina leucosticta & forest & insectivore & $0-1300$ & core \\
\hline Coereba flaveola & edge & frugivore & $0-1000$ & periphery \\
\hline Eucometis penicillata & forest & frugivore & $0-750$ & periphery \\
\hline
\end{tabular}


$4 *$ Presence/Absence data suggest species is extirpated. 


\section{Figure 1}

Comparative views of the Sierra de Los Tuxtlas from an artificially colorized 1979 Landsat image (top) and a 2010/11 Google Earth image (bottom) showing the extent of deforestation in the region. Remaining forest has become concentrated at higher elevatio

Comparative views of the Sierra de Los Tuxtlas from an artificially colorized 1979 Landsat image (top) and a 2010/11 Google Earth image (bottom) showing the extent of deforestation in the region. Remaining forest has become concentrated at higher elevations on the slopes of the region's three volcanoes, San Martín, Santa Marta, and San Martín Pajápan (the forested areas remaining, from left to right). 


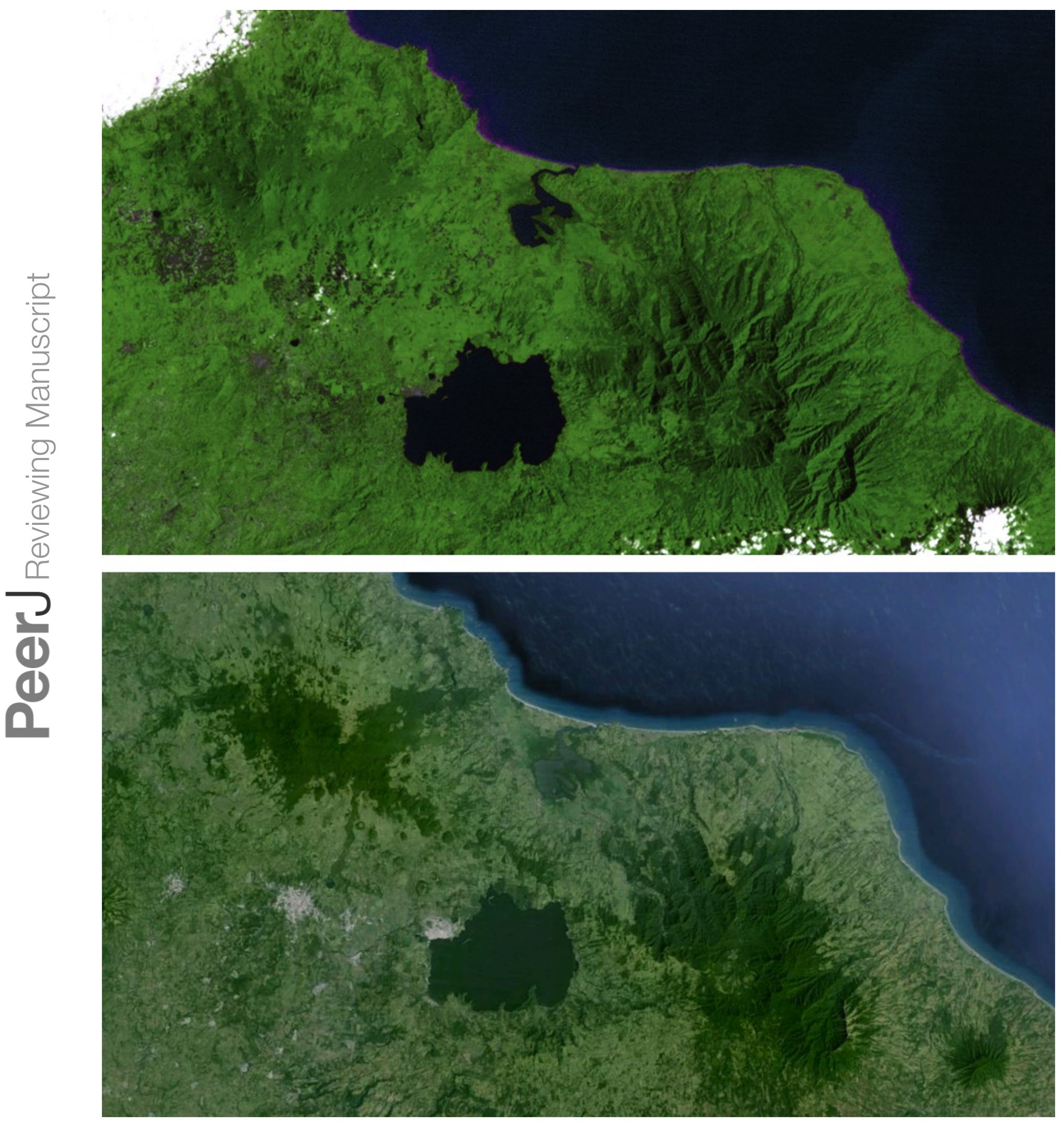




\section{Figure 2}

Satellite view of Volcán San Martín, the northernmost volcano in the Sierra de Los Tuxtlas, showing the distribution of forests (dark areas). The study area is indicated by the white box, which corresponds to the area in Fig. 3 (image from Google Earth, 2

Satellite view of Volcán San Martín, the northernmost volcano in the Sierra de Los Tuxtlas, showing the distribution of forests (dark areas). The study area is indicated by the white box, which corresponds to the area in Fig. 3 (image from Google Earth, 2010).

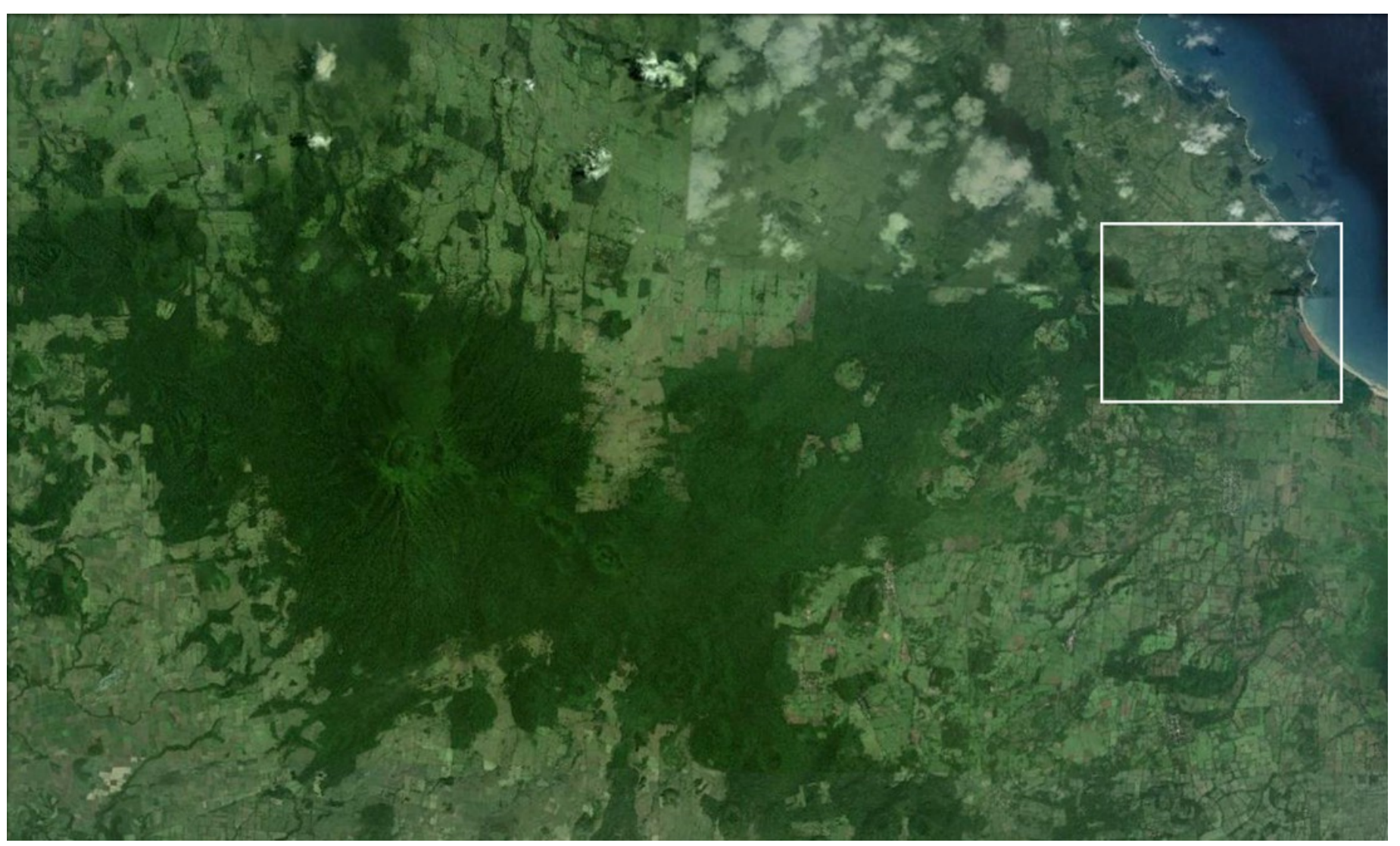




\section{Figure 3}

Maps of the study area in the northern lowlands of the Sierra de Los Tuxtlas (this is the area in the white box in Fig. 2) showing a rough outline of all forests types (dark gray areas) in 1979 (top, from Landsat image), in 2005 (bottom, from GoogleEarth)

Maps of the study area in the northern lowlands of the Sierra de Los Tuxtlas (this is the area in the white box in Fig. 2) showing a rough outline of all forests types (dark gray areas) in 1979 (top, from Landsat image), in 2005 (bottom, from GoogleEarth), and netting sites (black polygons). Numbers indicate field season(s) site was used and correspond to rows in Table 1. 


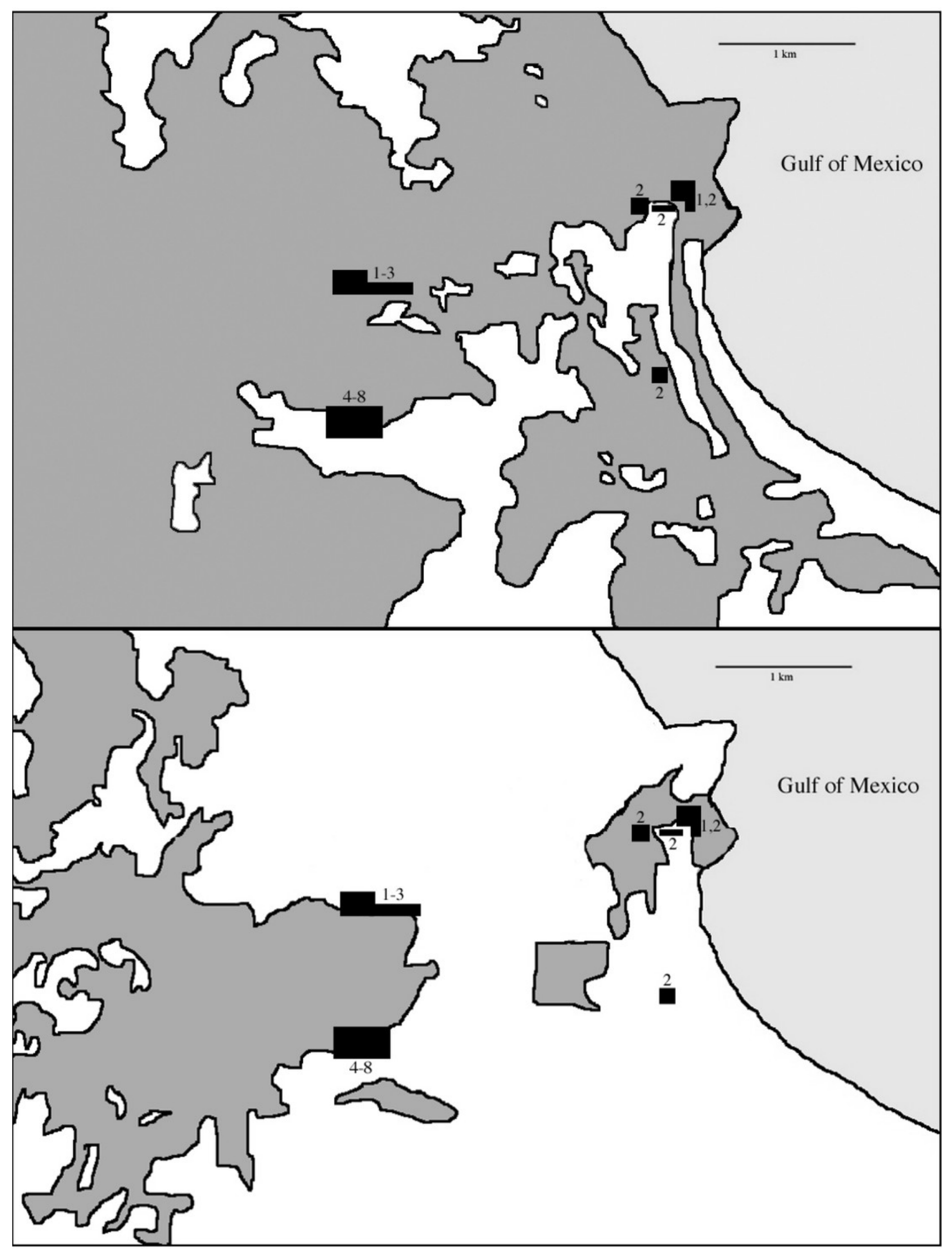

